\title{
PREPARATION AND CHARACTERIZATION OF GRAPHENE-BASED MAGNETIC HYBRID NANOCOMPOSITE
}

\author{
(Penyediaan dan Pencirian Nano Komposit Hibrid Magnetik Berasaskan Grafin) \\ Jashiela Wani Jusin ${ }^{1}$, Madzlan Aziz ${ }^{1,2 *}$, Goh Pei Sean ${ }^{2}$, Juhana Jaafar ${ }^{2}$ \\ ${ }^{1}$ Department of Chemistry, Faculty of Science \\ ${ }^{2}$ Advanced Membrane Technology Centre \\ Universiti Teknologi Malaysia, 81310 UTM Johor Bharu, Johor, Malaysia \\ *Corresponding author: madzlan@utm.my
}

Received: 9 December 2014; Accepted: 16 November 2015

\begin{abstract}
Graphene-based magnetic hybrid nanocomposite has the advantage of exhibiting better performance as platform or supporting materials to develop novel properties of composite by increasing selectivity of the targeted adsorbate. The hybrid nanomaterial was prepared by mixing and hydrolyzing iron (II) and iron (III) salt precursors in the presence of GO dispersion through coprecipitation method followed by in situ chemical reduction of GO. The effect of weight loading ratio of Fe to GO (4:1, 2.5:1, 1:1 and 1:4) on structural properties of the hybrid nanomaterials was investigated. The presence of characteristic peaks in FTIR spectra indicated that GO has been successfully oxidized from graphite while the decrease in oxygenated functional groups and peaks intensity evidenced the formation of hybrid nanomaterials through the subsequent reduction process. The presence of characteristic peaks in XRD pattern denoted that magnetite nanoparticles disappeared at higher loading of GO. TEM micrograph showed that the best distribution of iron oxide particles on the surface of hybrid nanomaterial occurred when the loading ratio of Fe to GO was fixed at 2:5 to 1 . The reduced graphene oxide (RGO) sheets in the hybrid materials showed less wrinkled sheetlike structure compared to GO due to exfoliation and reduction process during the synthesis. The layered morphology of GO degrades at higher concentrations of iron oxide.
\end{abstract}

Keywords: graphene, graphene oxide, surface modification, chemical co precipitation, magnetic nanoparticles

\begin{abstract}
Abstrak
Nano komposit hibrid magnetik berasaskan grafin mempunyai kelebihan dengan mempamerkan prestasi yang lebih baik sebagai platform atau bahan sokongan untuk mengembangkan sifat-sifat baharu komposit dengan meningkatkan pemilihan bahan terjerap yang disasarkan. Bahan nano hibrid telah disediakan dengan mencampurkan dan menhidrolisasikan pemula garam ferum (II) dan ferum (III) ke dalam sebaran GO melalui kaedah mendakan kimia diikuti oleh pengurangan kimia GO secara in situ. Kesan nisbah muatan berat Fe ke GO (4: 1, 2.5: 1, 1: 1 dan 1:4) terhadap sifat struktur bahan nano hibrid telah dikaji. Kehadiran puncak berciri dalam spektrum FTIR menunjukkan bahawa GO telah berjaya teroksida daripada grafit manakala penurunan dalam kumpulan berfungsi oksigen dan keamatan puncak membuktikan bahawa terdapat pembentukan bahan nano hibrid berikutan melalui proses pengurangan. Kehadiran puncak berciri dalam corak XRD menandakan bahawa nano zarah magnetit hilang apabila muatan GO lebih tinggi. Mikrograf TEM menunjukkan bahawa pengagihan zarah ferum oksida yang terbaik di atas permukaan bahan nano hibrid berlaku apabila nisbah muatan berat Fe ke GO ditetapkan pada 2: 5 ke 1. Kepingan grafin oksida yang melalui proses pengurangan (RGO) dalam bahan hibrid menunjukkan struktur kedutan yang berkurang berbanding GO disebabkan oleh proses pengelupasan dan pengurangan semasa sintesis. Lapisan morfologi GO berkurang pada kepekatan ferum oksida yang lebih tinggi.
\end{abstract}

Kata kunci: grafin, grafin oksida, pengubahsuaian permukaan, mendakan kimia, nano zarah magnet 


\section{Jashiela Wani et al: PREPARATION AND CHARACTERIZATION OF GRAPHENE-BASED MAGNETIC HYBRID NANOCOMPOSITE}

\section{Introduction}

Exposure to polluted water containing heavy metals and industrial waste can lead to major drawbacks to environment and pose risk to human health. In order to tackle these issues, various alternatives including membrane filtration [1], adsorption [2, 3], and ion exchange [4, 5] have been established. Recently, practical approaches have been made to develop a rapid nanocomposite adsorbent by incorporating magnetic nanoparticles (NPs) or nanocrystals into graphene or derivatives of graphene.

Graphene, a one-atom layer thick packed into a two-dimensional honeycomb $\mathrm{sp}^{2}$ carbon lattice is currently an emerging new material in the world of science and technology because of their unique and outstanding properties $[6,7]$. The production of graphene or reduced graphene oxide is preferably by using chemical route prior to its economical bulk synthesis. Meanwhile, high surface area and specific affinity for heavy metal adsorption from aqueous systems or wastewater samples can be provided by development of nanostructure metal oxides.

Among a wide range of magnetic materials, $\mathrm{Fe}_{3} \mathrm{O}_{4} \mathrm{NPs}$ are becoming the topic of interest due to their unique magnetic separation performances by simply applying an external magnetic field. Besides that, magnetite nanoparticles are very well known for their established application in water treatment. In addition, magnetic particles-based composite adsorbents allowed rapid isolation from aqueous solutions for recycling or regeneration. The great advantage that arises from these two outstanding materials is essential to reduce the cost and time required for water or wastewater treatment.

$\mathrm{Wu}$ et al. reported the preparation of a graphene-based magnetic nanocomposite for the extraction of carbamate pesticides from environmental water samples [8]. Sheng et al. developed a versatile magnetic graphene oxide which has performed an efficient removal of arsenate [9]. Fan et al. also fabricated magnetic $\beta$-cyclodextrinchitosan/graphene oxide as nanoadsorbent and applied into the application of removal and dye adsorption [10]. Despite having a lot of advantages, the formation of magnetic nanoparticles with graphene or its derivatives may involve particles aggregation thus the process remains challenging.

In this study, a graphene-based magnetic hybrid nanocomposite consisting magnetic nanoparticles that were incorporated on the surface of reduced graphene oxide through chemical co-precipitation of iron chloride salts solution and subsequent reduction of graphene oxide was developed. The properties of this hybrid material prepared with different loading ratios of graphene oxide and iron salt precursors were investigated. The synthesized nanomaterials were characterized by X-ray diffraction (XRD) and transmission electron microscopy (TEM) to study the nanoparticles crystallinity and morphology, respectively. The chemical compositions of the hybrid materials were investigated by Attenuated Total Reflectance Infrared spectroscopy (ATR-IR). It was expected that the further optimization of these hybrid materials based on various parameters such as type of reducing agent, reaction time, stirring rate and synthesis temperature can be implemented to produce a promising adsorbent for water treatment.

\section{Materials and Methods}

The materials used in the experiments were included of commercial graphite powder $(60-85 \%)$ supplied by Superior Graphite Co. while hydrochloric acid $(\mathrm{HCl}, 37 \%)$, sodium hydroxide $(\mathrm{NaOH})$, hydrazine hydrate $\left(\mathrm{N}_{2} \mathrm{H}_{4} \cdot \mathrm{H}_{2} \mathrm{O}\right)$, and sulfuric acid $\left(\mathrm{H}_{2} \mathrm{SO}_{4}, 95-97 \%\right)$ were from Merck. Potassium permanganate $\left(\mathrm{KMnO}_{4}, 99 \%\right)$ was purchased from Bendosen. Hydrogen peroxide $\left(\mathrm{H}_{2} \mathrm{O}_{2}, 35 \%\right)$, ferric chloride hexahydrate $\left(\mathrm{FeCl}_{3} \cdot 6 \mathrm{H}_{2} \mathrm{O}\right)$ and ethanol $\left(\mathrm{C}_{2} \mathrm{H}_{6} \mathrm{O}\right)$ were supplied from $\mathrm{QReC}$. Sodium nitrate $\left(\mathrm{NaNO}_{3}\right)$ and ferrous chloride tetrahydrate $\left(\mathrm{FeCl}_{2} \cdot 4 \mathrm{H}_{2} \mathrm{O}\right)$ were obtained from Systerm. All materials were used as received. Distilled water was used throughout this study.

\section{Preparation of Graphene Oxide (GO) films}

Graphite oxide was first prepared from graphite powder in the presence of strong oxidizing agents according to modified Hummers method [11]. The proportion was scaled down during the synthesis process. Graphite powder (2 g) and $\mathrm{NaNO}_{3}(1 \mathrm{~g})$ were gradually added to a cold concentrated $\mathrm{H}_{2} \mathrm{SO}_{4}(98 \%, 46 \mathrm{ml})$ followed by 30 minutes stirring in an ice bath. Subsequently, $\mathrm{KMnO}_{4}(6 \mathrm{~g})$ was slowly added to the mixture while maintaining the temperature below $20^{\circ} \mathrm{C}$. After 2 hours stirring, the ice bath was removed and the mixture was stirred at $35^{\circ} \mathrm{C}$ for 30 minutes until it became pasty brownish. The reaction was continued with the addition of distilled water $(92 \mathrm{~mL})$ 
resulting in sudden increase of the reaction temperature to $90-98{ }^{\circ} \mathrm{C}$ which was maintained for 15 minutes. The mixture was diluted with distilled water and subsequently, $\mathrm{H}_{2} \mathrm{O}_{2}(30 \%, 10 \mathrm{~mL})$ was added to stop the oxidation process resulting the mixture turned to bright yellow with few bubbles existed. The mixture was left overnight with continuous stirring to make sure its homogeneity. The mixture then was centrifuged, rinsed with $5 \% \mathrm{HCl}$ solution to remove the residual metal ions followed by distilled water for several times to obtain neutral $\mathrm{pH}$. Graphite oxide solution was subjected to ultrasonication to produce graphene oxide (GO). The resulting slurry was dried at $70{ }^{\circ} \mathrm{C}$ for 24 hours to obtain GO films.

\section{Preparation of $\mathrm{Fe}_{3} \mathrm{O}_{4}$-RGO Hybrid Nanomaterials}

The procedure was modified from the previous literature where the molar ratio of $\mathrm{Fe}^{3+}: \mathrm{Fe}^{2+}$ was fixed as $2: 1$ to synthesize the $\mathrm{Fe}_{3} \mathrm{O}_{4}$ nanoparticles [12]. $\mathrm{GO}(200 \mathrm{mg})$ was dispersed in distilled water (200 mL) by ultrasonication for 30 minutes to transform the carboxylic acid groups to carboxylate anions. Then $\mathrm{FeCl}_{3} \cdot 6 \mathrm{H}_{2} \mathrm{O}(0.04 \mathrm{~mol})$ and $\mathrm{FeCl}_{2} \cdot 4 \mathrm{H}_{2} \mathrm{O}(0.02 \mathrm{~mol})$ were dissolved in distilled water $(100 \mathrm{~mL})$, which then was added drop wise to GO dispersion at room temperature with vigorous stirring followed by sonication process for 30 minutes. Subsequently, $50 \mathrm{wt} \% \mathrm{NaOH}$ solutions was added drop wise. The $\mathrm{pH}$ was constantly monitored to make solution of $\mathrm{pH} 11-12$. The temperature of the solution was raised to $80{ }^{\circ} \mathrm{C}$ and hydrazine hydrate $(1.5 \mathrm{~mL})$ was added with constant stirring for reduction of GO, resulting in a black solution. After being rapidly stirred for 5 hours the solution was continuously stirred for 12 hours at room temperature. The resulting precipitate was thoroughly washed with distilled water ( 3 times) and then followed by ethanol ( 3 times) to remove any impurities. The products were centrifuged for 15 minutes at $3000 \mathrm{rpm}$ to discard excess water. The precipitate then was dried at $60{ }^{\circ} \mathrm{C}$ for 8 hours. The dry product was then grinded into a fine powder. The same procedures were repeated to prepare different $\mathrm{Fe}$ to GO weight loading ratios of 1:1, 2.5:1. 4:1 and 1:4 (labeled as Fe/RGO 1:1, Fe/RGO 2.5:1, Fe/RGO 4:1, Fe/RGO $1: 4$ respectively).

\section{Characterization of GO films and hybrid nanomaterials}

FTIR was used to determine the chemical compositions of the prepared GO and hybrid nanomaterials. The prepared samples were characterized by using Attenuated Total Reflectance-Fourier Transform Infrared spectrometer (ATRFTIR) with a resolution of $4 \mathrm{~cm}^{-1}$. The crystallinity of GO and hybrid nanomaterials were examined based on XRD patterns obtained from PANalytical X'Pert Pro MPD HR-X-ray diffractometer, powered by Philips PW3040/60 with $\mathrm{Cu}-\mathrm{K}_{\alpha}$ radiation $(\lambda=1.5418 \AA$ ) generated from a Cu anode supplied with $40 \mathrm{kV}$ and a current of $30 \mathrm{~mA}$. The scan range for $2 \theta$ was from 5 to $90^{\circ}$. The surface morphology of the prepared samples was studied based on the TEM images captured with FEI/Philips CM12 transmission electron microscope operated at $120 \mathrm{kV}$.

\section{Fourier Transform Infrared spectrometer (FTIR)}

\section{Results and Discussion}

Figure 1 shows the FTIR spectra of graphite and graphene oxide (GO). The presence of few significant characteristic peaks in GO can be associated to the presence of oxygenated functional groups which were resulted from successful oxidation of graphite. The broad adsorption band at $3230.2 \mathrm{~cm}^{-1}$ is assigned to the $\mathrm{O}-\mathrm{H}$ stretching vibrations while two adsorption bands appear at $1716.7 \mathrm{~cm}^{-1}$ and $1625.6 \mathrm{~cm}^{-1}$ are corresponding to the $\mathrm{C}=\mathrm{O}$ stretching (from carbonyl and carboxyl groups) and aromatic $\mathrm{C}=\mathrm{C}$ vibration (resulted from skeletal vibration from unoxidized graphitic domains) respectively. The peak observed at $1386.1 \mathrm{~cm}^{-1}$ can be assigned to the combination of $\mathrm{C}-\mathrm{O}$ (carboxy) stretching vibration and deformation vibration of hydroxyl groups. Another peak presents at 1048.8 $\mathrm{cm}^{-1}$ can be attributed to the C-O (alkoxy) stretching vibration.

Figure 2 illustrated the FTIR spectra of GO and the hybrid nanocomposite with different loading ratio. The appearance of peak at 500-600 $\mathrm{cm}^{-1}$ differs GO from the hybrid nanocomposite in which it denoted the presence of Fe-O. The peak intensity of the hybrids was found to be very similar to each other except for Fe/RGO 1:4 which probably due to the higher loading ratio of GO presented in the hybrid. In general, the FTIR absorption bands of the hybrid nanocomposite showed much lower intensity compared to that of GO. The observation suggested that the oxygenated functional groups were partially removed from GO during the reduction process using hydrazine hydrate where GO has transformed into reduced graphene oxide (RGO) during the synthesis [13]. 
Jashiela Wani et al: PREPARATION AND CHARACTERIZATION OF GRAPHENE-BASED MAGNETIC HYBRID NANOCOMPOSITE

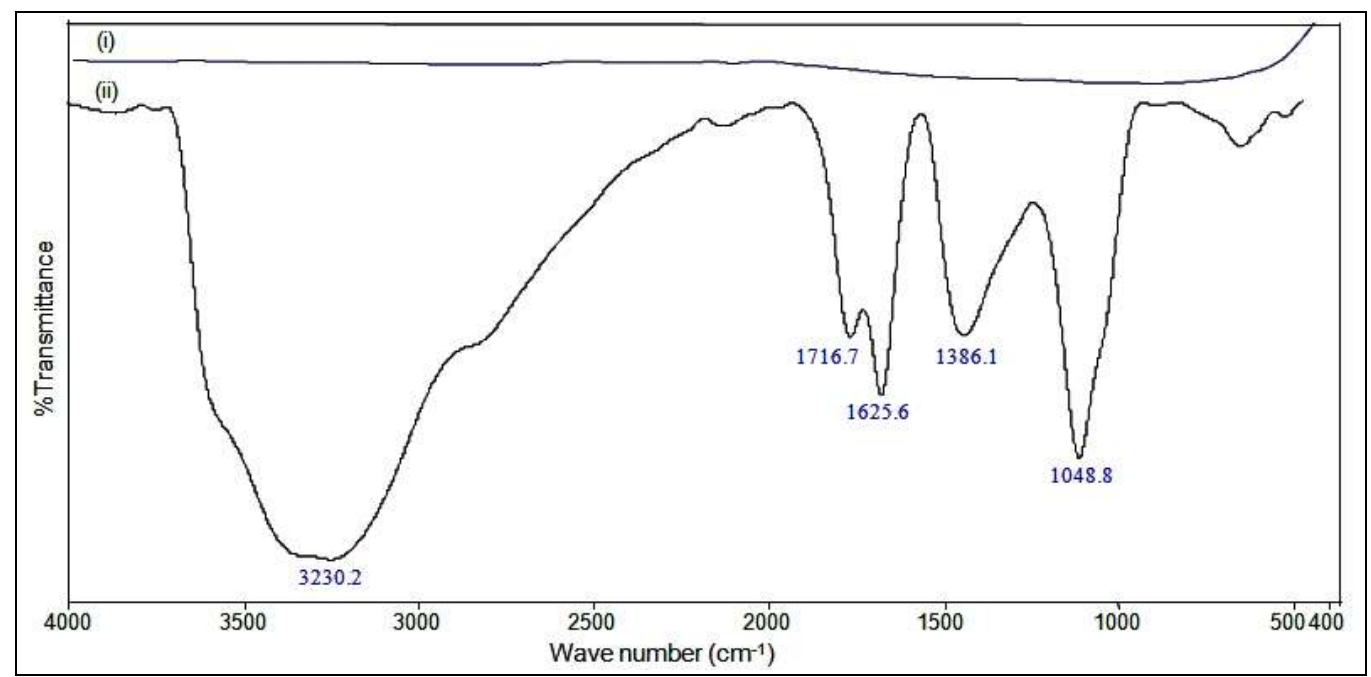

Figure 1. FTIR spectra comparison of (i) graphite and (ii) GO

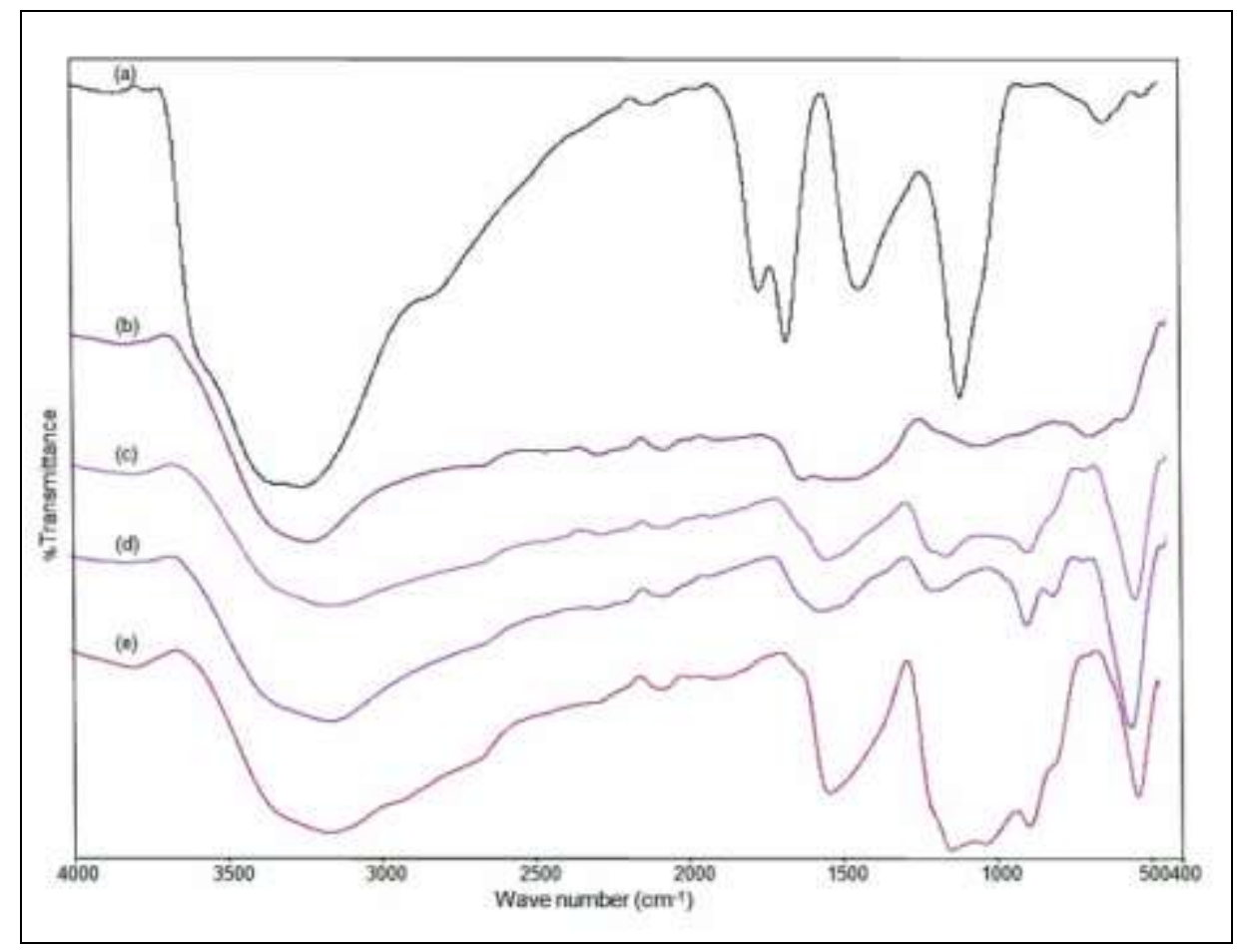

Figure 2. FTIR spectra comparison of (a) GO and hybrid nanomaterials with different weight loading ratios (b) Fe/RGO 1:4, (c) Fe/RGO 2.5:1, (d) Fe/RGO 4:1, and (e) Fe/RGO 1:1 respectively 


\section{X-Ray Diffraction (XRD)}

XRD analysis was used to further confirm and compare the crystalline structure and composition of the obtained hybrid nanomaterials. XRD patterns of graphite, graphene oxide (GO) and hybrid materials synthesized at different weight loading ratios are shown in Figure 3. Graphite shows a very sharp diffraction peak at $2 \theta=26.5^{\circ}$ which corresponds to $d$-spacing of $0.34 \mathrm{~nm}$ with an index (002). Meanwhile, GO exhibits typical diffraction peaks centered at $2 \theta=11.5^{\circ}(001)$ corresponding to interlayer distance of $\sim 0.77 \mathrm{~nm}$ and $2 \theta=22.3^{\circ}(100)$ which is consistent with the previous report [14]. The diffraction peak appears from GO is originated from (002) layer plane from graphite. The interlayer $d$-spacing of graphene oxide $(0.77 \mathrm{~nm})$ tends to be much larger than graphite $(0.34$ $\mathrm{nm})$ due to the presence of many oxygen functionalities that attached to the surfaces of GO with some potential defects related to the strong oxidation process. A broad diffraction peak appears at $2 \theta \approx 22.3^{\circ}$ due to the short range order of stacked graphene sheets.

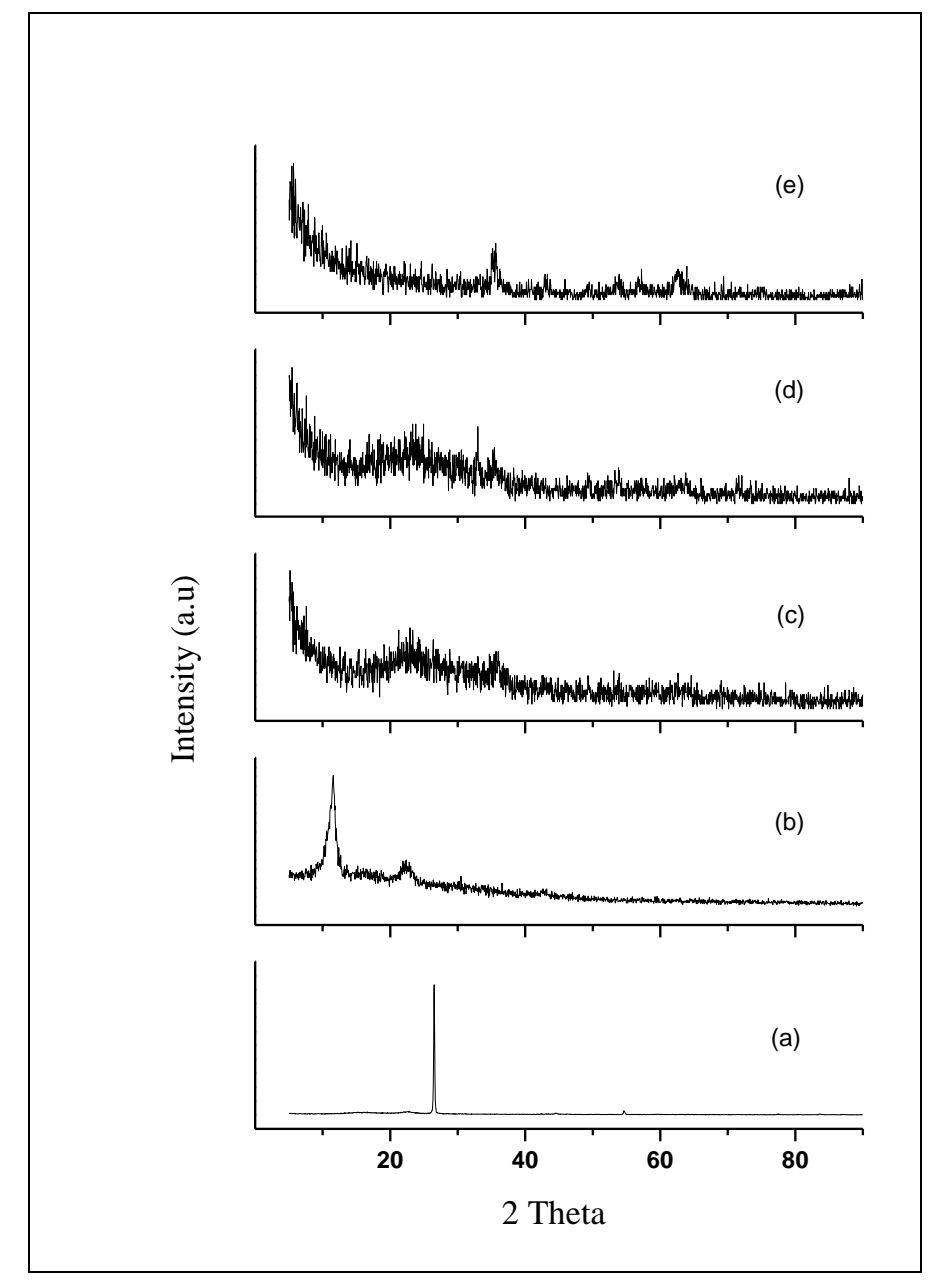

Figure 3. XRD patterns of (a) graphite, (b) GO, (c) Fe/RGO 1:1, (d) Fe/RGO 1:4, and (e) Fe/RGO 2.5:1

The XRD patterns of Fe/RGO nanocomposite with ratio of $1: 1$ and 1:4 are very similar. Both Fe/RGO 1:1 and $\mathrm{Fe} / \mathrm{RGO} 1: 4$ showed the most intense diffraction peaks at $2 \theta \approx 24^{\circ}$ and $23^{\circ}$ respectively corresponding to the peak resulted from GO. However, both Fe/RGO 1:1 and Fe/RGO 1:4 do not show any peak that is corresponding to the magnetite compound. The Fe/RGO 1:1 is less likely to show magnetic properties due to the presence of minute amount of $\mathrm{Fe}_{2} \mathrm{O}_{3}$ particles in their composite. There are some diffraction peaks that are indexed to $\mathrm{Fe}_{3} \mathrm{O}_{4}$ particles in 
Fe/RGO 2.5:1 with low intensity as compared to pure magnetic particles. The peaks of Fe/RGO 2.5:1 appear at $2 \theta$ $\approx 19.3^{\circ}(111), 35.4^{\circ}(311), 43.1^{\circ}(400), 53.7^{\circ}(422)$ and $62.5^{\circ}(440)$ indicated the characteristic of $\mathrm{Fe}_{3} \mathrm{O}_{4}$ nanoparticles while $2 \theta \approx 24.5^{\circ}$ corresponds to the peak resulted from GO. However, formation of magnetite particles was not pure and might contain $\mathrm{Fe}_{2} \mathrm{O}_{3}$ particles and it was shown by at least two peaks of (220) and (511) indexes were missing. The synthesis reaction that was not carried out under nitrogen flow might be the reason for the unsuccessful magnetite formation since the ratio between $\mathrm{Fe}^{2+}$ and $\mathrm{Fe}^{3+}$ was probably disturbed during the fabrication process [15]. By using Scherer formula, average particle size of Fe/RGO 2.5:1 is estimated as $11.8 \mathrm{~nm}$.

\section{Transmission Electron Microscope (TEM)}

The surface morphology of GO and the hybrid nanocomposites were studied by TEM whereby only GO and Fe/RGO nanocomposite with weight loading ratio of 2.5:1 and 1:4 were chosen as the representative samples (Figure 4). TEM analysis was performed on these two hybrids because Fe/RGO 2.5:1 presented the most significant characteristic peaks of XRD pattern while the analysis on Fe/RGO 1:4 was carried out to confirm that the higher loading ratio of GO might contribute to the disappearance of Fe-O absorption peak in the respective FTIR spectra. From the obtained TEM micrographs, there is significant difference between the as-prepared GO and RGO sheets in Fe/RGO 2.5:1 and Fe/RGO 1:4 hybrid. The RGO sheets present in the Fe/RGO 2.5:1 hybrid show less wrinkled sheet-like structure compared to GO and Fe/RGO 1:4 hybrid probably due to the exfoliation and reduction process during the synthesis. It has also been reported that, the layered morphology of GO tends to degrade at higher concentrations of iron oxide [16].
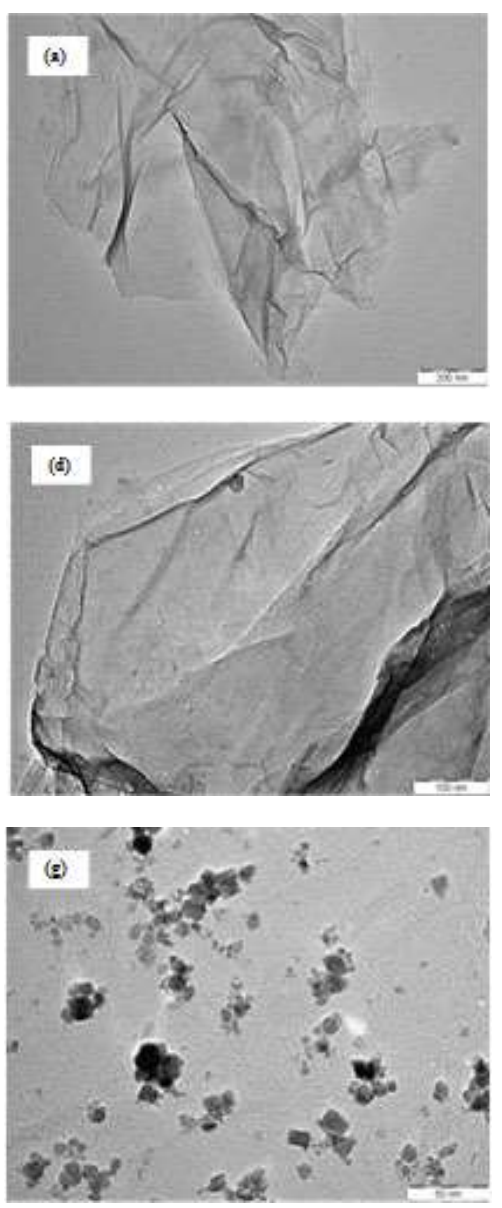
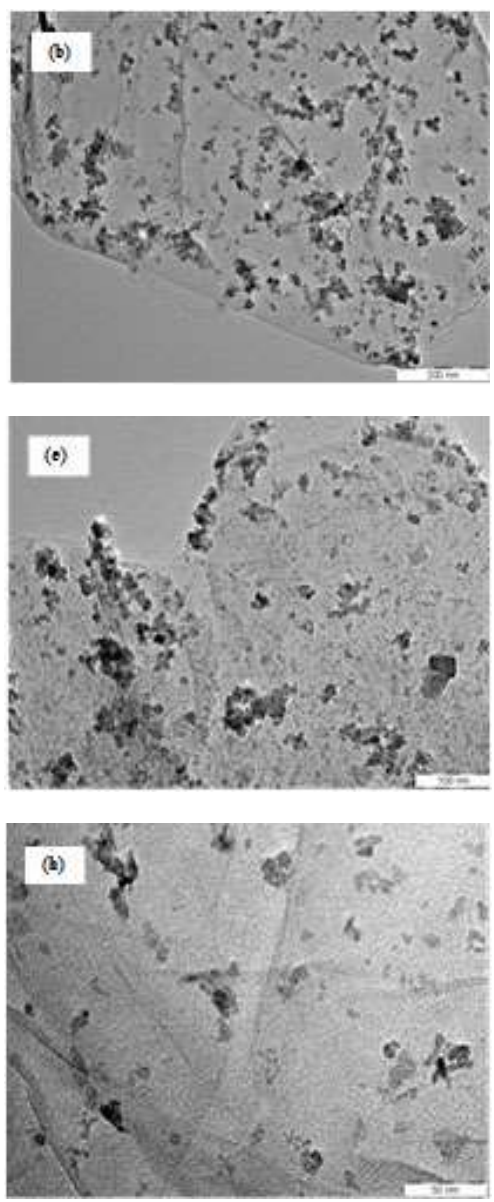
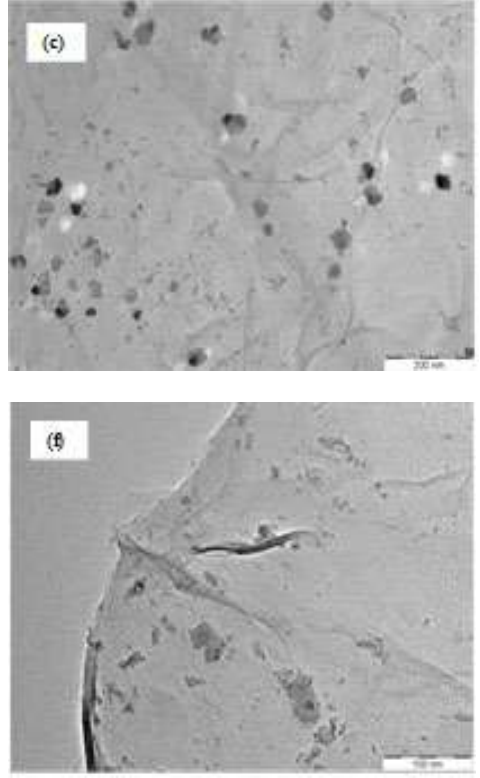

Figure 4. TEM micrographs of GO, Fe/RGO 2.5:1 and Fe/RGO 1:4 at magnification of $200 \mathrm{~nm}$ : (a, b, c), $100 \mathrm{~nm}$ : $(\mathrm{d}, \mathrm{e}, \mathrm{f})$ and $50 \mathrm{~nm}:(\mathrm{g}, \mathrm{h})$ respectively 


\section{Conclusion}

The study on fabrication of hybrid nanomaterials was conducted by incorporating graphene oxide (GO) and magnetic nanoparticles altogether to achieve enhanced properties of conventional nanocomposite. The oxygen-rich functional groups allow GO to carry out secondary functionalization for the preparation of hybrid nanomaterials. In this study, magnetic hybrid materials were developed through chemical co precipitation from the mixture of iron (II) and iron (III) salt precursors, followed by in situ chemical reduction process of GO. From the FTIR spectra, it was shown that GO exhibited significant difference from graphite in terms of the amount of oxygenated functional groups. On the other hand, the hybrid nanomaterials exhibited absorption bands with much lower intensity compared to that of GO due to the partial removal of oxygenated functional groups during the reduction process. As higher loading of GO may have restricted the formation of iron particles onto the GO surface, the characteristic peaks that corresponding to magnetite nanoparticles were absent in the XRD patterns. The layered morphology of RGO sheets in hybrid nanocomposites showed less wrinkled sheet-like structure as compared to GO due to the exfoliation during the reduction process and probably because of the increasing iron oxide content. This study has shown that weight loading ratio of $\mathrm{Fe}$ to GO has significant effect in term of morphological and structural properties of the hybrid nanocomposites.

\section{Acknowledgement}

The authors acknowledge Ministry of Education Malaysia (MOE), Research Grant No. 4F257 and Universiti Teknologi Malaysia for the provided facilities and financial support throughout this study.

\section{References}

1. Blöcher, C., Dorda, J., Mavrov, V., Chmiel, H., Lazaridis, N. K. and Matis, K. A. (2003). Hybrid flotationmembrane filtration process for the removal of heavy metal ions from wastewater. Water Research, 37(16): $4018-4026$.

2. Kadirvelu, K., Thamaraiselvi, K. and Namasivayam, C. (2001). Removal of heavy metals from industrial wastewaters by adsorption onto activated carbon prepared from an agricultural solid waste. Bioresource Technology, 76(1): $63-65$.

3. Katsou, E., Malamis, S. and Haralambous, K. J. (2011). Industrial wastewater pre-treatment for heavy metal reduction by employing a sorbent-assisted ultrafiltration system. Chemosphere, 82(4): $557-564$.

4. Dabrowski, A., Hubicki, Z., Podkościelny, P. and Robens, E. (2004). Selective removal of the heavy metal ions from waters and industrial wastewaters by ion-exchange method. Chemosphere, 56(2): $91-106$.

5. Qdais, H. A. and Moussa, H. Removal of heavy metals from wastewater by membrane processes: a comparative study. Desalination, 164(2): $105-110$.

6. Geim, A. K. and Novoselov, K. S. (2007) The rise of graphene. Nature Materials, 6(3): 183 - 191.

7. Novoselov, K. S., Geim, A. K., Morozov, S.V., Jiang, D., Katsnelson, M. I., Grigorieva, I. V., Dubonos, S. V. and Firsov, A. A. (2005) Two-dimensional gas of massless Dirac fermions in graphene. Nature, 2005. 438(7065): $197-200$.

8. Wu, Q., Zhao, G., Feng, C., Wang, C. and Wang, Z. (2011). Preparation of a graphene-based magnetic nanocomposite for the extraction of carbamate pesticides from environmental water samples. Journal of Chromatography A, 1218(44): 7936 - 7942.

9. Sheng, G., Li, Y., Yang, X., Ren, X., Yang, S., Hu, J. and Wang, X. (2012). Efficient removal of arsenate by versatile magnetic graphene oxide composites. RSC Advances, 2(32): 12400 - 12407.

10. Fan, L., Luo, C., Sun, M., Qiu, H. and Li, X. (2013). Synthesis of magnetic $\beta$-cyclodextrin-chitosan/graphene oxide as nanoadsorbent and its application in dye adsorption and removal. Colloids and Surfaces B: Biointerfaces, 2013. 103: $601-607$.

11. Hummers, W.S. and Offeman, R.E. (1958). Preparation of Graphitic Oxide. Journal of the American Chemical Society, 80(6): $1339-1339$.

12. Yao, Y., Miao, S., Liu, S., Ma, L.P., Sun, H. and Wang, S. (2012). Synthesis, characterization, and adsorption properties of magnetic Fe3O4@graphene nanocomposite. Chemical Engineering Journal, 184(0): 326 - 332.

13. Ji, Z., Shen, X., Song, Y. and Zhu, G. (2011). In situ synthesis of graphene/cobalt nanocomposites and their magnetic properties. Materials Science and Engineering: B, 176(9): 711 - 715. 
14. Zhu, S., Guo, J., Dong, J., Cui, Z., Lu, T., Zhu, C., Zhang, D. and Ma, J. (2013). Sonochemical fabrication of $\mathrm{Fe} 3 \mathrm{O} 4$ nanoparticles on reduced graphene oxide for biosensors. Ultrasonics Sonochemistry, 20(3): 872 - 880.

15. Chia, C. H., Zakaria, S., Farahiyan, R., Liew, T. K., Khien L. N., Abdullah, M. and Ahmad, S. (2008). Sizecontrolled Synthesis and Characterization of $\mathrm{Fe} 3 \mathrm{O} 4$ Nanoparticles by Chemical Coprecipitation Method. Sains Malaysiana, 37(4): 389 - 394.

16. Singh, V. K., Patra, M. K., Manoth, M., Gowd, G. S., Vadera, S. R. and Kumar, N. (2009). In situ synthesis of graphene oxide and its composites with iron oxide. New Carbon Materials, 24(2): 147 - 152.

17. Guo, J., Wang, R., Tjiu, W., Pan, J. and Liu, T. (2012). Synthesis of Fe nanoparticles@ graphene composites for environmental applications. Journal of Hazardous Materials, 225-226: 63 -73. 